\title{
アンカ一体摩擦応力に対するグラウト加圧注入の効果 \\ Effects of pressure grout injection for the anchor body friction stress
}

\author{
片山直樹a) b) * \\ Naoki KATAYAMA
}

\begin{abstract}
About the effects that pressure grout injection performed by ground anchor give to the function of the anchor and the increase mechanism of the anchor body surface friction stress with it, there are many points that are not yet clear. This is because it is hard to perform constant evaluation for the effects of the pressure grout injection to be affected by the inhomogeneous nature greatly on the natural ground. Therefore, in this study, I made two types of specimens which cast grout by presence of the pressurization for the homogeneous model ground which removed inhomogeneity and measured the friction stress between ground materials and grout by direct shear test. As a result, a good relationship was recognized between increase of the friction stress by the pressure grout injection and the dehydration phenomenon of the grout, and recognized the strength increase of the dehydrated grout. From these results, the increase mechanism of the anchor body surface friction stress in the homogeneous ground by the pressure grout injection estimated it to be a thing by the increase of the cohesive power by the strength increase with the dehydration of the grout.
\end{abstract}

Key words : Ground Anchor, Grout, Pressure Grout Injection, Friction Stress

\section{和文要旨}

グラウンドアンカーで行われる加圧注入が，アンカーの機能に及ぼす効果や，それに伴うアンカー体周面摩擦応力の増加メカニ ズムについては，いまだ明らかでない点が多い。この一因として，自然地盤ではその不均質性に大きく影響を受けるため，加圧注 入の効果に対する一定の評価が得られにくいことが挙げられる。そこで本研究では, 不均質性を排除した均質なモデル地盤に対し, 加圧の有無によりグラウトを打設した 2 種類の供試体を作製し，一面せん断試験により地盤材とグラウト間の摩擦応力を測定した。 その結果, 加圧注入による摩擦応力の増加とグラウトの脱水現象には良好な関係性が認められ, 脱水したグラウトの強度増加も確 認された。これらの結果から, 均質地盤における加圧注入によるアンカー体周面摩擦応力の増加メカニズムは, 加圧脱水に伴うグ ラウトの高強度化に起因する付着力の増加によるものと推定した。

キーワード：グラウンドアンカー, グラウト, 加圧注入, 摩擦応力

\section{1.はじめに}

グラウンドアンカー（以下，アンカーとする）のアン カー体注入では，一般に加圧注入が行われている。加圧 注入は，削孔の影響などによる孔壁の緩みを防止すると ともに，アンカー体グラウトと周面地盤との接触面にお ける摩擦応力（以下， $\tau$ とする）を増加させる目的で行 われる ${ }^{1)}$ 。また，礫質土や砂質土などの間隙が多い地盤 では，加圧注入によりグラウトを地盤中に浸透させ，ア ンカー体径の肥大効果によるての増加も期待されている

しかしながら，グラウトの浸透など注入形態の不確か さなどから，加圧注入の効果について疑問視される場合 もあるように ${ }^{3)}$, 加圧注入によるグラウトの注入形態や, それに伴うての変化については，いまだ不明確な部分が 多く残されている。

薬液注入の分野では，加圧注入による薬液の注入形態 として，大別すると浸透注入と割裂注入の 2 つの概念が ある。アンカーのグラウトとして一般的に使用される水 セメント比 $W / C=50 \%$ 前後のセメントミルクでは, 粘 土層などの間隙比が小さな地盤への浸透注入は不可能と され，主に割裂注入の形態をとるとされている4)。ただ

* 連絡著者/corresponding author

a 株式会社日本海技術コシサルタンツ

Nihonkai Technical Consultants CO., Ltd

厂 $699-0403$ 島根県松江市穴道町西来待 $2570-1$

7599-0403 島根県松江市宾道町西来待2570-1 b) 山口大学大学院
し，一般的なアンカーでは，加圧力を高め地盤に割裂を 生じさせ，その亀裂にグラウトを注入することは一般に 行われていない( ${ }^{5) \sim 7) 。 ~}$

セメントミルクなどの懸濁液型注入材料の浸透性を評 価する指標の一つであるグラウタビリティ比（土粒子の $10 \%$ 粒径 $D_{10} /$ 注入材の $95 \%$ 粒径 $\left.G_{95}\right)$ からの判断では, 普通セメントを使った場合, 浸透注入が可能となる $D_{10}$ は $0.56 \mathrm{~mm}$ 以上となることから ${ }^{4)}$, 細粒分を多く含み均 質かつ密な状態の自然地盤に対しては加圧注入によるグ ラウトの浸透は起こり難いといえる。

また，グラウトの注入挙動に関する研究 ${ }^{8), 9)}$ によると， 均質地盤においては $W / C=350 \%$ 以下のセメントミル

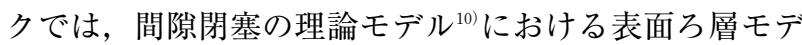
ル（濁質粒子が間隙内に浸入できず表面に蓄積されるモ デル）の状態となり，グラウトの浸透は非常に困難であ ることが示されている。

以上のように，アンカーの加圧注入によるグラウトの 浸透は困難であるといえ，これに伴うアンカー体径の変 化に起因したての増加は生じ難いといえる。

一方で，グラウトの加圧力および加圧時間と $\tau$ の関係 に関する研究結果 ${ }^{11)}$ では，加圧注入によるての増加は， 加圧によりアンカー体周面地盤が改良される影響である と結論づけており，加圧注入の効果およびてへの影響に ついては議論の余地が残されているように思われる。 


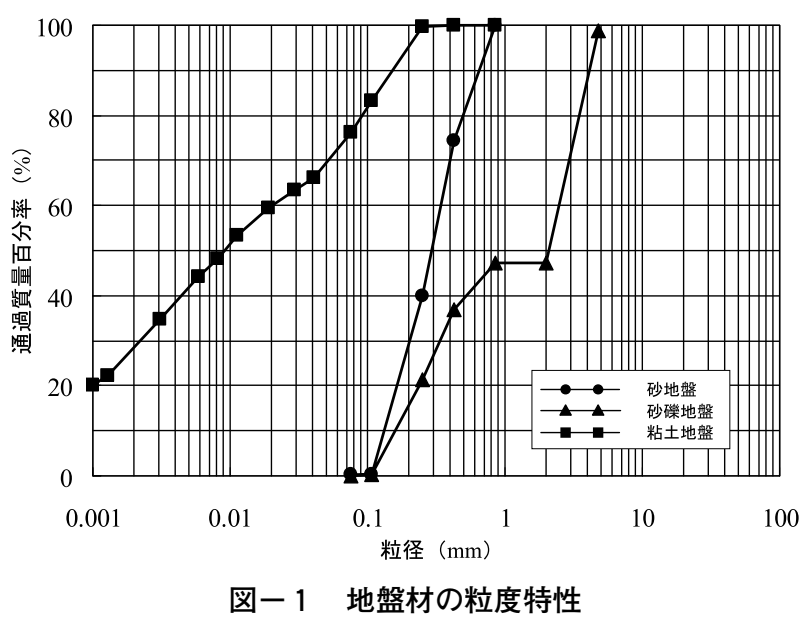

Fig. 1 Grading curves of ground materials

自然地盤における加圧注入の効果は，地盤の不均質性 に左右される要素を多く含むために，アンカー打設現場 の地質・土質条件や削孔条件の影響を強く受ける。この ため, 加圧注入とての関係性について明らかにすること は容易ではない。

これまでの自然地盤におけるアンカーに関する既往研 究および調査は, 現場条件の違いや地盤の不均質性の影 響を受けているといえ，まだ加圧注入の有効性およびて への影響について普遍的な関係性を見出すには至ってい ない。

そこで, 本研究では不均質性を排除した均質なモデル 地盤について，グラウトの打設条件を変えた供試体を作 製し, 地盤材とグラウト接触面の $\tau$ 一面せん断試験に より測定した。その試験結果をもとに，加圧注入がグラ ウトやその注入過程に及ぼす効果ならびに $\tau$ の増加メカ ニズムについて考察した。

\section{2. 試験方法}

\section{1 試験概要}

実際のアンカー引抜き時には，多様なせん断破壊面が 生じるため，アンカー体周面に発現するてに対する一定 の評価を行い難い。よって本研究では，この様なせん断 破壊面の影響を極力抑えるために，任意の面におけるせ ん断が可能である一面せん断試験によりグラウトと地盤 材間のせん断強さを測定した。なお，既往研究 ${ }^{12), 13) て ゙ は ~}$ 一面せん断試験により砂や粘性土などの地盤材料と, 鋼 材やコンクリートなどの構造物材料間のせん断強さを測 定し，材料間の摩擦係数として評価したものもみられる。 したがって, 本研究では測定されたせん断強さを, グラ ウトと地盤材間で発現する摩擦応力として評価する。

また, 既往研究により模型アンカーの 3 次元円筒形モ デルと 2 次元的平面モデルでは, 引抜き量と引抜き抵抗 力の関係に同様の傾向が認められている ${ }^{14)}$ 。したがって, 本研究では 3 次元的なアンカー体と周面地盤間のせん断 問題を，簡便な平面的せん断問題に近似できるものとし
た。

試験は, 直径 $6 \mathrm{~cm}$, 高さ $6 \mathrm{~cm}$ の筒状のモデル地盤 の上に, セメントミルクによるグラウトを打設した供試 体を作製し，モデル地盤とグラウトの接触面に対して一 面せん断試験を実施し，せん断強さを求めた。

試験に用いた地盤材は, 砂地盤, 砂礫地盤, 粘土地盤 を想定した 3 種類の均質材料とした。各地盤材の粒度特 性および物理特性をそれぞれ図 -1 ，表－ 1 に示す。

また，グラウトの打設方法は，加圧する場合としない 場合の 2 種類とし，それぞれの試験結果を比較すること で加圧注入がてに及ぼす影響を評価した。

\section{2 試験供試体の作製}

内径 $6 \mathrm{~cm}$ の円筒状である専用型枠下側の底部に, 排 水性・排気性を確保するために厚さ $1 \mathrm{~cm}$ のポーラスス トーンを敷き，その上に地盤材を密に詰めて作製した。

砂地盤は, 鳥取砂丘砂（平均粒径 $D_{50}=0.288 \mathrm{~mm}$ ) を 水洗いしたものを専用型枠に入れ，水を加えながら締め 固め，均質な密地盤を作製した。

砂礫地盤は，砂地盤で使用した鳥取砂丘砂に粒径 $\phi 2$ 〜 4.75mmに調整した花崗岩の細礫を質量比で $1 ： 1$ の 割合でよく混ぜて均質化し $\left(D_{50}=2.335 \mathrm{~mm}\right)$, 砂地盤 同様に水締めして密な状態とした。

粘土地盤は, 島根県産来待砂岩の粉体に加水して作っ た粘土（ $D_{50}=0.009 \mathrm{~mm} ）$ を用いた。粘土を型枠に木製 ランマー（直径 $1 \mathrm{~cm} ）$ で突き固めながら充填し, 十分 密な状態となるようにして地盤を作製した。

モデル地盤を作製した後，専用型枠上側を取り付け， 上端部開口部からグラウト（早強セメント $W / C=50 \%$, $\mathrm{P}$ ロートによるフロー值 $15 \pm 3$ 秒）を流し込み，加圧す る場合としない場合で 2 種類作製した。

グラウトを加圧する場合は，グラウトを流し込んだ後 に，電動エアーポンプを上端部開口部に接続し，空気圧 を加えることによりグラウトの加圧注入を再現した。加 圧力は地盤の種類によらず $200 \mathrm{kN} / \mathrm{m}^{2}$ とし, 圧力保持時 間については 1 分間とした。グラウトは，打設後完全に 硬化する前に，専用型枠上側を外し，厚さ $1 \mathrm{~cm}$ なる ように上部をカットして整形した（図－2）。

\section{3 一面せん断試験}

試験供試体のグラウトを 3 日間養生した後，一面せん 断試験（JGS0561）を行った。

\section{表一 1 地盤材の物理特性}

Table 1 Physical characteristic of ground materials

\begin{tabular}{cccc}
\hline & 砂地盤 & 砂礫地盤 & 粘土地盤 \\
\hline 工学的分類 $(\mathrm{JGS0051)}$ & $\mathrm{S}$ & $\mathrm{GS}$ & $\mathrm{CLS}$ \\
土粒子密度 $\rho_{s}\left(\mathrm{~g} / \mathrm{cm}^{3}\right)$ & 2.689 & 2.645 & 2.599 \\
湿潤密度 $\rho_{t}\left(\mathrm{~g} / \mathrm{cm}^{3}\right)$ & 1.70 & 1.73 & 1.88 \\
含水比 $(\%)$ & 15.7 & 12.7 & 23.0 \\
間隙比 & 0.83 & 0.72 & 0.70 \\
透水係数 $(\mathrm{cm} / \mathrm{s})$ & $5.1 \times 10^{-3}$ & $1.4 \times 10^{-3}$ & $1.0 \times 10^{-6}$ \\
\hline
\end{tabular}




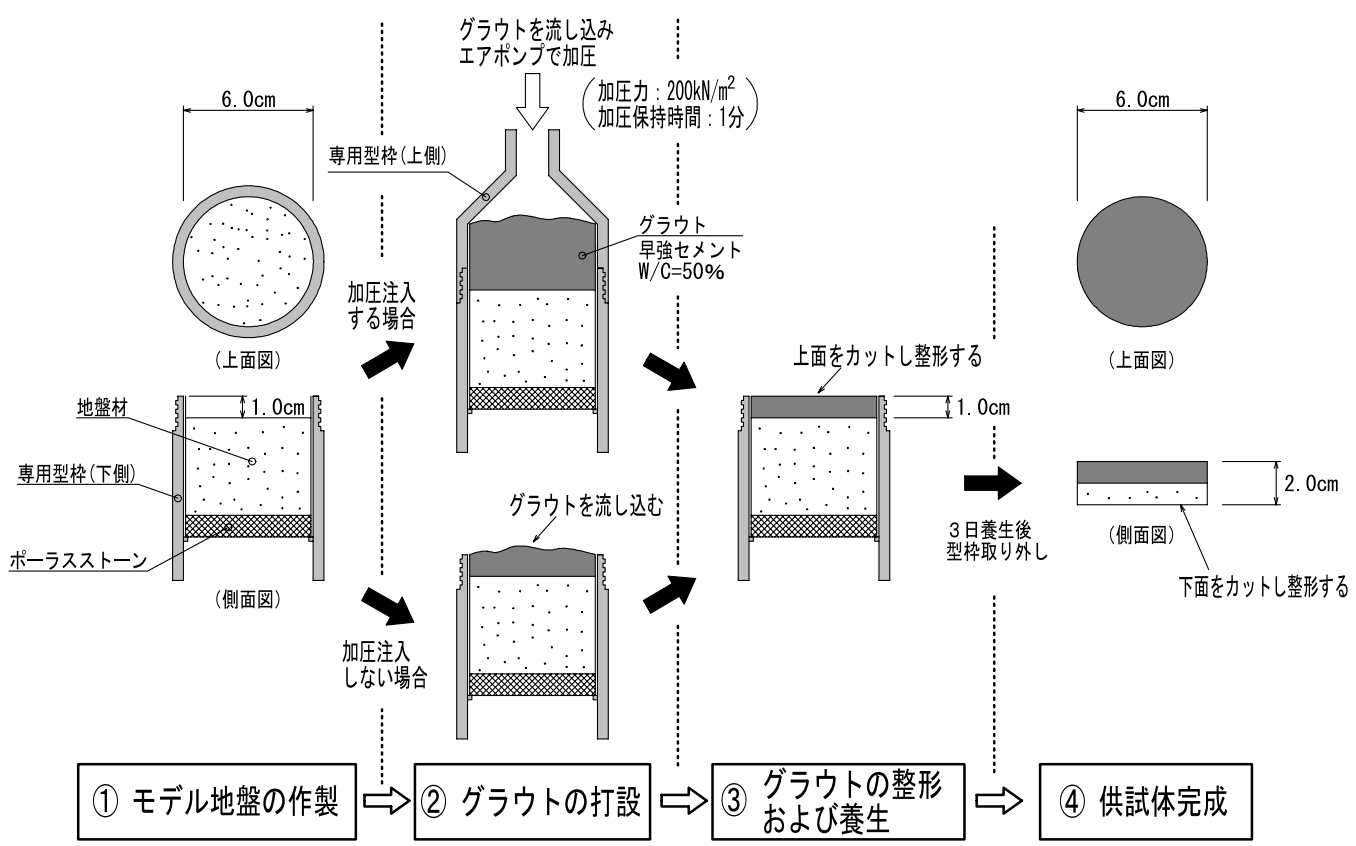

図一２供試体作製方法

Fig. 2 Specimens manufacture method

専用型枠から取り出した供試体は，一面せん断試験機 にセットするために，モデル地盤側を $1 \mathrm{~cm}$ の厚さにカッ トし，供試体全体の厚さを $2 \mathrm{~cm}$ に整形した。

一面せん断試験は全ての地盤材において定圧試験によ るものとし，垂直応力 $\sigma_{v} を 50 \sim 400 \mathrm{kN} / \mathrm{m}^{2}$ 間で変化させ て試験を行った。圧密過程で変位量が十分落ち着いた後, せん断変位速度を $0.2 \mathrm{~mm} / \mathrm{min}$ でせん断を行い，定圧せ 几断強さ（以下， $\tau_{f}$ とする）を測定した。

\section{3. 試験結果}

\section{1 地盤材のせん断強度特性}

モデル地盤自体のせん断強度特性を把握するために, それぞれの地盤材についても一面せん断試験を行った。 得られたて とそれらに対する近似直線を図ー 3 に示す。 なお，砂地盤については粘着力が認められた結果となっ たが，これは供試体の含水比が $16 \%$ 程度の含水状態で あったため，見かけの粘着力が発現した影響と考えられ る。

\section{2 試験結果}

\subsection{1 砂地盤の場合}

砂地盤の供試体に扔ける一面せん断試験の結果を図一 4 にまとめる。

得られたて子にはばらつきが認められたが，全体的には グラウトを加圧した場合の方が大きい $\tau_{f}$ が発現する結果 となった。特にその傾向は $\sigma_{v}$ が低圧時ほど顕著に現れて おり， $\sigma_{v}=50 \mathrm{kN} / \mathrm{m}^{2}$ 時に扔ける $\tau_{f}$ の平均值は，加圧供試 体が無加圧供試体の1.49倍であった。祙のばらつきの程 度は，加圧供試体の方が大きい傾向が認められ，最もば らつきが大きかった $\sigma_{v}=100 \mathrm{kN} / \mathrm{m}^{2}$ 時の標準偏差は 54.6 であった。

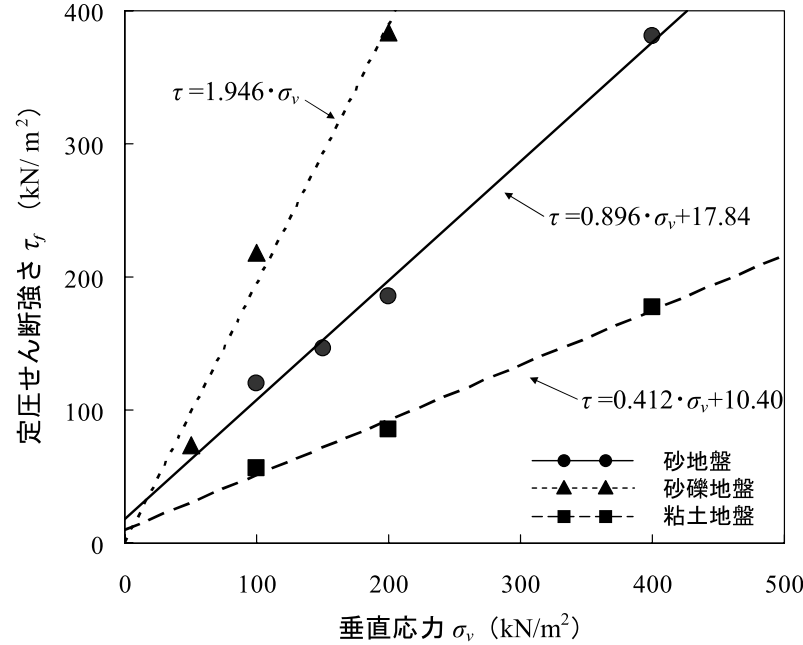

図一３地盤材のせん断強度特性

Fig. 3 Shear strength characteristic of ground materials

また，一部の加圧供試体（図－4のム）において，他 のデータと比べ高い $\tau_{f}$ が発現した。これらの供試体につ いては，試験後のせん断面がやや下に凸になっていたこ とが確認された（写真－1）。これはグラウトと地盤材 間の付着性が向上したため，せん断破壊面が地盤材内に 形成され，正のダイレイタンシーが生じて高い $\tau_{f}$ が発現 したものと推測される。

このようにせん断面が地盤材内に形成されたものにつ いては，正確にはグラウトと地盤材間の摩擦応力を示さ

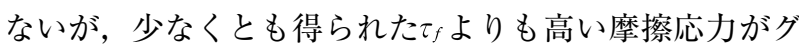
ラウトと地盤材間で発現しているものと予測される。し たがって，本研究においてはこれら地盤材内にせん断面 が生じた試験結果についても加圧供試体の $\tau_{f}$ として評価 した。 


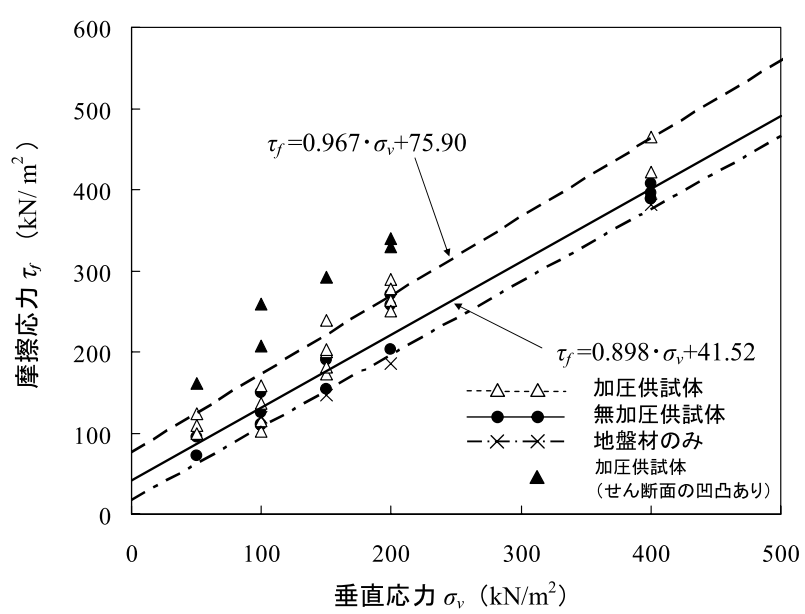

図一 4 砂地盤における摩擦応力と垂直応力の関係

Fig. 4 Relationship between friction stress and vertical stress in specimens of sand material

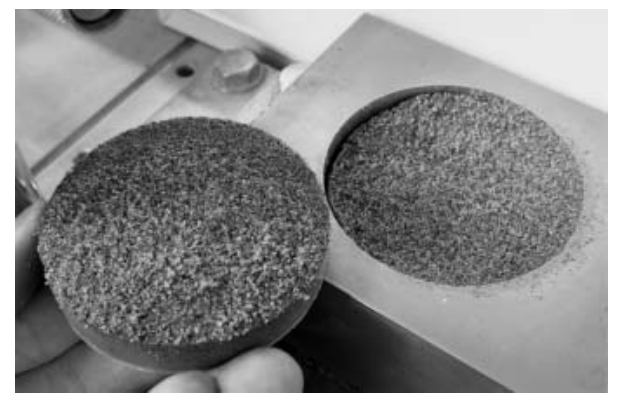

写真－1 試験後のせん断面（砂地盤 $\sigma_{v}=100 \mathrm{kN} / \mathrm{m}^{2}$ ） Photo 1 Shearing plane after test (sand material, $\sigma_{v}=100 \mathrm{kN} / \mathrm{m}^{2}$ )

なお，せん断面が地盤材内に形成されたものを除けば 祙のばらつきは小さいといえることから，データのばら つきは地盤材内に形成されるせん断面の不確実性に起因 するものと推測される。

試験後，供試体の地盤材部分にフェノールフタレイン 溶液を吹付け，グラウトの浸透状況を確認したが，加圧 の有無にかかわらずグラウトの浸透は認められなかった。 しかし，加圧を行った供試体については，加圧後のグラ ウトはかなり粘性の高い状態を呈しており，加圧による 脱水現象が認められた。

\subsection{2 砂碟地盤の場合}

砂礫地盤に打ける一面せん断試験の $\tau_{f}$ を図 -5 にまと

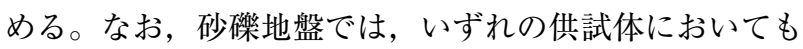
高い $\tau_{f}$ が発現したため, 使用した一面せん断試験機の荷 重計の許容量の関係から， $\sigma_{v}=200 \mathrm{kN} / \mathrm{m}^{2}$ より大きい垂 直応力での試験は実施できなかった。

砂礫地盤における試験結果では，グラウトの加圧と無 加圧による $\tau_{f}$ の差異が明瞭に表れ，全ての $\sigma_{v}$ 条件下にお いて，加圧した場合の $\tau_{f}$ の方が高い結果が示された。砂 地盤の結果と同様に， $\sigma_{v}$ が低圧時ほどその傾向が顕著に 表れ， $\sigma_{v}=50 \mathrm{kN} / \mathrm{m}^{2}$ 時においては加圧供試体の $\tau_{f}$ が無加 圧供試体の 1.53 倍であった。また，加圧後のグラウトは

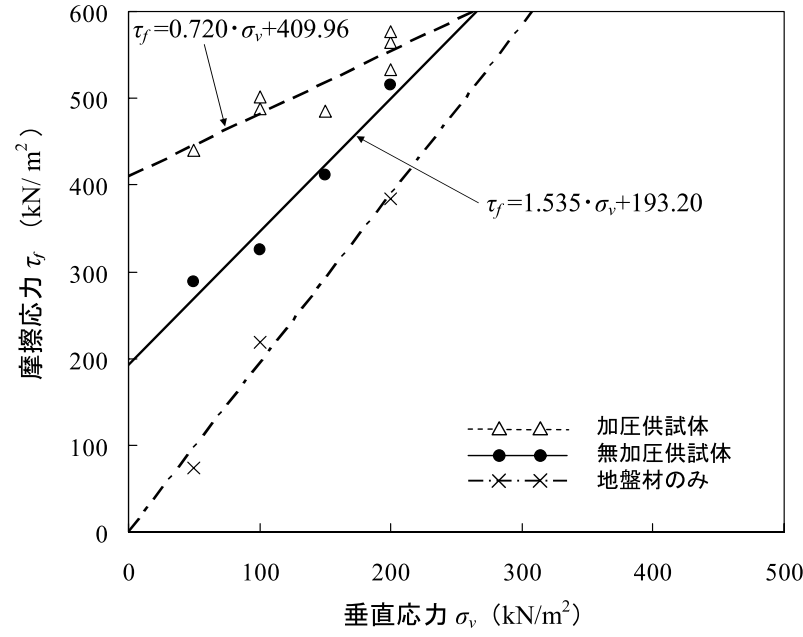

図一 5 砂砵地盤における摩擦応力と垂直応力の関係

Fig. 5 Relationship between friction stress and vertical stress in specimens of gravel material

著しく脱水された状態にあり，グラウトのみで自立が可 能な半固体状を示した (写真 -2$)$ 。

フェノールフタレイン溶液により加圧注入によるグラ ウトの浸透状況を調べたところ，グラウトとの接触部か ら $2 \mathrm{~cm}$ 程度内部までが赤く染まり，アルカリ分が浸透 した状況であることが示された（写真-3）。しかし， 試験後に加圧注入を行った供試体を崩し, 地盤材内部の グラウト浸透状況を確認したところ，硬質な状態のグラ ウトは接触面から $2 \mathrm{~mm}$ 程度内部までの範囲の, 鿬によ る表面的な凹凸を充填する程度であった。それより内部 の地盤材に認められたフェノールフタレイン溶液の反応 は，微量のセメント粒子が浸透した影響と考えられ， $\tau_{f}$ に与えた影響は低いものと推察される。

なお，無加圧注入による供試体においても，地盤材の 表面的な凹凸はグラウトにより充填されており，目視レ ベルでは加圧供試体と同様であることを確認した。

\subsection{3 粘土地盤の場合}

粘土地盤における一面せん断試験の $\tau_{f}$ を図 -6 にまと める。全体的には砂地盤に比べ $\tau_{f}$ のばらつきの程度は小 さいが，グラウトの加圧と無加圧による $\tau_{f}$ の差異が不明 瞭な結果といえる。今回の試験結果では， $\sigma_{v}$ が $200 \mathrm{kN} /$ $\mathrm{m}^{2}$ よりも低い場合には加圧による $\tau_{f}$ の増加傾向がわずか に認められたものの，それ以上の $\sigma_{v}$ 条件下となると加圧 条件に関わらず $\tau_{f}$ のばらつきが大きくなり一意の傾向が 認められない結果となった。このような高い $\sigma_{v}$ 条件下に おける $\tau_{f}$ のばらつきは，圧密過程において供試体の粘土 に塑性変形が生じ，グラウトと粘土の付着性が損なわれ た影響である可能性が考えられる。

一面せん断試験後の供試体地盤材部分にフェノールフ タレイン溶液を吹付けたが，アルカリ分の浸透は認めら れなかった。また，加圧供試体の加圧後のグラウトは， 他の地盤材ほどではないが若干の脱水が確認できた。

\section{3 グラウトの一軸圧縮強さの違い}




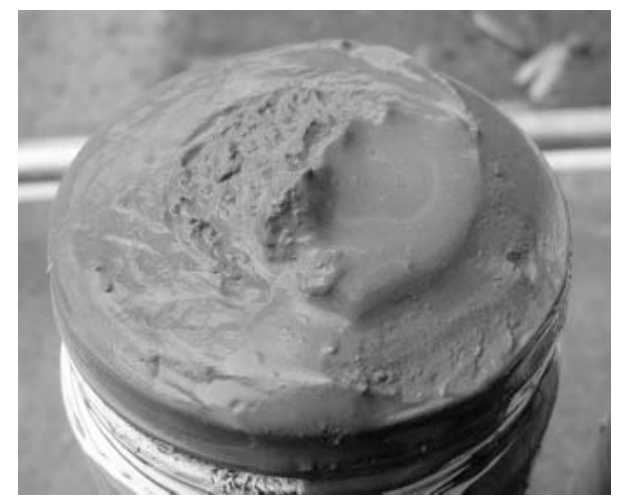

写真一 2 加圧後のグラウト脱水 (砂礫地盤) Photo 2 Grout dehydration after pressurization (gravel material)

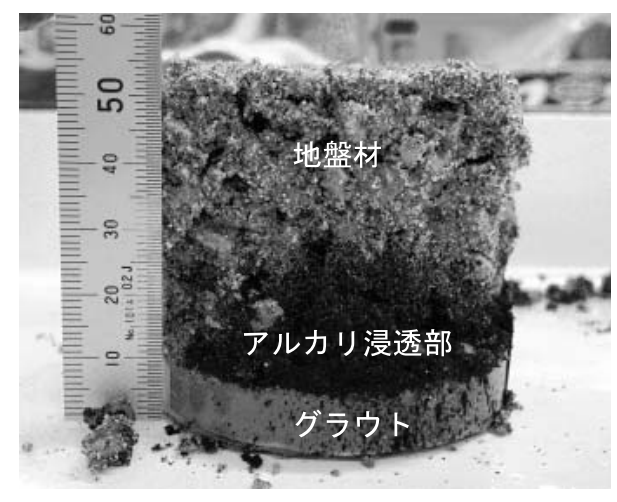

写真一 3 加圧後のアルカリ浸透（砂碟地盤）

Photo 3 Alkali penetration after pressurization (gravel material)

加圧注入の供試体においてグラウトの脱水が認められ, 特に砂地盤，砂磦地盤での脱水が著しくみられた。この 脱水作用がグラウトの強度に及ぼす影響をみるために, 供試体を作製し一軸圧縮試験（JIS A1216）を行った。

供試体は，グラウト（早強セメント $W / C=50 \%, \mathrm{P}$ ロートによるフロー值18秒）を，砂の地盤材を詰めた専 用型枠に加圧注入し脱水させたものと, 脱水させないも のをプラスチックモールド（直径 $5 \mathrm{~cm}$ ，高さ $10 \mathrm{~cm}$ ）に 入れ，それぞれ 4 個ずつ供試体を作製し，2日養生後に 一軸圧縮試験を行った。試験結果を図 - 7 に示す。

一軸圧縮試験の結果，無加圧グラウトの一軸圧縮強さ $q_{u}$ は平均 $q_{u}=18.57 \mathrm{MN} / \mathrm{m}^{2}$ に対し，加圧グラウトは平均 $q_{u}=31.99 \mathrm{MN} / \mathrm{m}^{2}$ と 1.72 倍強度が高い結果となった。ま た，加圧し脱水させたグラウトの方が $q_{u}$ の個体差が小さ いことが認められた。

試験供試体の湿潤密度 $\rho_{t}$ および含水比 $w の$ 平均值は, 無加圧グラウトが $\rho_{t}=1.778 \mathrm{~g} / \mathrm{cm}^{3}, w=28.2 \%$ に対し， 加圧グラウトは $\rho_{t}=1.929 \mathrm{~g} / \mathrm{cm}^{3}, w=19.7 \%$ ありり，加 圧グラウトの方が密実な状態であることが示された。

これらのことから，加圧注入により脱水したグラウト は密実化し，それに伴う強度の増加および発現強度の安 定が図れるものと判断される。

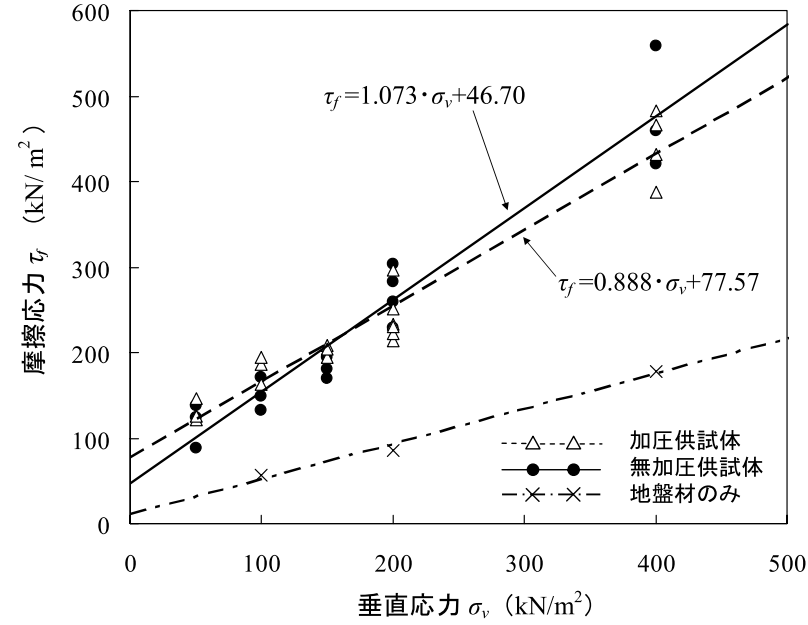

図－6 粘土地盤における摩擦応力と垂直応力の関係

Fig. 6 Relationship between friction stress and vertical stress in specimens of clay material

\section{4. 考察}

\section{1 加圧注入によるグラウトの注入過程}

均質地盤に対するセメントベースのグラウトの注入過 程は，セメント粒子の輸送過程，地盤間隙へのセメント 粒子の充填過程および充填されたグラウト材の硬化過程 から成り立っているとされる ${ }^{15)}$ 。なお，本文ではセメン 卜粒子の輸送過程をグラウトの浸透過程と同義として扱 うものとする。

上記の過程のうち浸透過程については，セメントミル クなどの懸濁液型注入材料は，前述のとおり均質な地盤 内に浸透するためには $W / C=350 \%$ 以上でなければ浸 透は困難であることから，一般的なアンカーにおける $W / C=50 \%$ 前後のグラウトでは浸透は生じ難いと考え られる。

今回の試験結果では，砂地盤および粘土地盤による加 圧供試体については，グラウトの浸透は全く認められな かった。これはグラウトが $W / C=50 \%$ あったため， 表面ろ層状態となりグラウトの浸透が生じなかったもの と判断される。一方，砂礫地盤による加圧供試体につい てはフェノールフタレイン溶液の反応から，わずかにセ メントのアルカリ分の浸透が認められたが，固化体を形 成するほどのセメント量は浸透しておらず，グラウトが 浸透したとは言い難い。

これらの結果から，加圧注入によるグラウトの注入過 程を考えると，アンカー定着層とされるような密実な自 然地盤であり，かつ，均質な状態の地盤においては，グ ラウトの浸透過程は発生しないものと推定される。すな わち，アンカー工におけるグラウトの加圧注入では，グ ラウトの浸透によるアンカー体径の肥大効果や，それに 伴った $て$ 増加は期待できないものと判断される。

既往研究におけるアンカー体の掘り出し結果 ${ }^{16)}$ (18) にお いても，比較的密な土丹層や砂層では加圧注入によるア ンカー体径が削孔径と同等もしくは1.1倍程度であった 


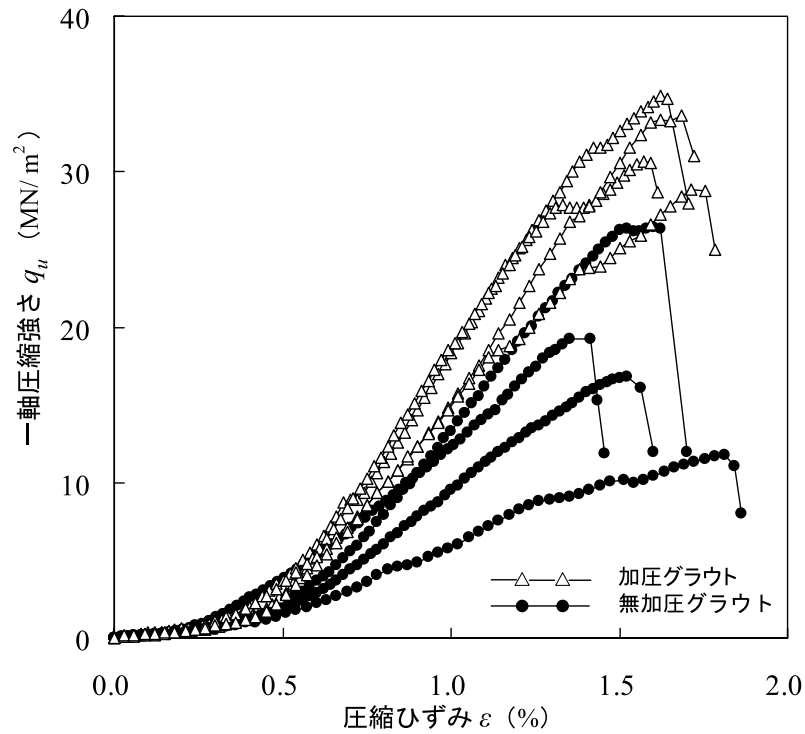

図ー 7 グラウトの一軸圧縮試験結果

Fig. 7 Uniaxial compression test results of grout

報告もあり，今回の試験結果と調和的であることから， 上記の解釈が自然地盤の均質部においては当てはまるも のといえよう。

一方，砂砂地盤についてはアンカー体径の肥大効果が 著しい報告が多くみられる。掘り出し後のアンカー体の 状態19)から判断すると, 加圧注入によるグラウトの浸透 によるアンカー体径の肥大ではなく，削孔の影響などに より生じた孔壁の凹凸にグラウトが充填された結果と考 えられる。

これらのことから，自然地盤におけるグラウトの加圧 による注入過程としては, 浸透過程はなく, 孔壁から連 続する亀裂や間隙などへの充填過程がそのほとんどであ ると推定される。

\section{2 加圧注入によるグラウトの品質向上}

加圧注入し脱水が生じたグラウトについて，2日養生 後の一軸圧縮強さを測定したところ，無加圧状態で打設 したグラウトと比して平均值で約1.7倍高い值を示した。 これは，コンクリートの加圧養生と同じく，グラウトに 含まれる余分な水分を加圧注入により強制的に搾り出す ことでグラウトの密度を高め, 高強度化したためと考え られる。

このことから，グラウトの加圧注入は，注入過程の最 後である硬化過程に対しても良好な影響を及ぼすことが 確認された。すなわち，加圧注入を行うことで，より密 実なアンカー体造成に寄与できるものと考えられ，これ により水密性や耐ブリージング性の向上を図ることがで き，養生後のアンカー体周面の付着力低下を抑制する効 果をもつものと判断される。

また，脱水させたグラウトの一軸圧縮強さの方が値の ばらつきが少ない傾向が認められたことから，加圧注入 を行うことでアンカー体のグラウトの品質を安定させる 効果もあるものと思われる。
ただし，これらの効果は加圧注入によりグラウトの脱 水が行われる場合のみ期待できるため, 透水性の低い粘 土や岩盤に対しては効果的ではないといえよう。

\section{3 加圧注入による}

アンカー体周面に発現するては，グラウトと地盤の付 着力, 地盤自体の強度, 接触面の面積㧍よびその形状に 大きく影響を受けると考えられる。

今回の試験結果では, 加圧によるグラウトの浸透が認 められなかったことから，加圧の有無によるグラウトと 地盤材間の接触面積およびその形状に差はなかったもの と判断できる。また，地盤材の作製方法も同一であった ことから地盤材の強度差もない。したがって, 今回の試 験で認められた $\tau_{f}$ の差は, グラウトと地盤の付着力の差 である可能性が示唆される。

砂抢よび砂礫の地盤材を用いた試験結果には, 加圧の 有無により $\tau_{f}$ に有意な差異が認められ，特に低 $\sigma_{v}$ 時の差 が顕著であった。また，図 $-4 \sim 6$ に示す $\tau_{f}-\sigma_{v}$ 関係か ら， $\tau_{f}$ をクーロン式により粘着力 $c$ とせん断抵抗角 $\phi$ に分 解した結果, 全ての地盤材において加圧供試体の $c$ 值が 1.5倍以上大きい值となることが確認された（表-2）。

垂直応力の大小に依存しない強度定数である $c$ 值は, グラウトと地盤材の付着力の大きさをそのまま反映して いると判断される。このことからも，加圧注入の影響に よりグラウトと地盤の付着力が強化され, その結果 $\tau_{f}$ が 増加したものと推定される。

このように, 加圧供試体の付着力が増加した要因とし ては, 試験結果に有意な差異が認められた砂地盤打よび 砂礫地盤において, 顕著にみられたグラウトの脱水現象 が考えられる。砂地盤に扔けるグラウトの加圧・脱水に 伴う含水比の変化とグラウトの $q_{u}$ 拉よび $\rho_{t}$, せん断面の $\tau_{f}\left(\sigma_{v}=50 \mathrm{kN} / \mathrm{m}^{2}\right.$ 時の平均值 $)$ およびcの関係を図 -8 にまとめる。

図ー8より，加圧による脱水が行われたグラウトは， その密度が増加し, それに伴い一軸圧縮強さも増してい ることが読み取れる。また，グラウトと地盤間の付着力 と評価される $c$ 值も脱水に伴う強度増加が認められ，同 様な傾向であることが示されている。これらの傾向から， 脱水により高密度化抢よび高強度化したグラウトは地盤 との付着力が増加し, その結果 $\tau_{f}$ 増加したものと判断 される。したがって, グラウトの脱水現象と $\tau_{f}$ の増加に は良好な関倸性が認められた結果といえる。

以上のことから, 均質地盤に扔けるグラウトの加圧注 入によるての増加メカニズムは, グラウトの浸透による 効果はなく, グラウトの脱水現象に起因する強度増加に 伴った付着力増加による部分が大きいと考えられる。

\section{5. まとめ}

本研究では砂・砂磁・粘土の 3 種類のモデル地盤に対 し，グラウトを加圧もしくは無加圧の状態で打設した供 試体を作製し, それらについて一面せん断試験を行い, 
表一 2 せん断強度 $\tau_{f}$ からの $c$ 値

Table 2 Cohesion from share strength

\begin{tabular}{ccc}
\hline 地盤材 & 加圧状 況 & $c\left(\mathrm{kN} / \mathrm{m}^{2}\right)$ \\
\hline \multirow{2}{*}{ 砂 } & 加 圧 & 75.9 \\
& 無加 圧 & 41.5 \\
砂 磎 & 加 圧 & 410.0 \\
& 無加 圧 & 193.2 \\
粘 土 & 加 圧 & 77.6 \\
& 無加 圧 & 46.7 \\
\hline
\end{tabular}

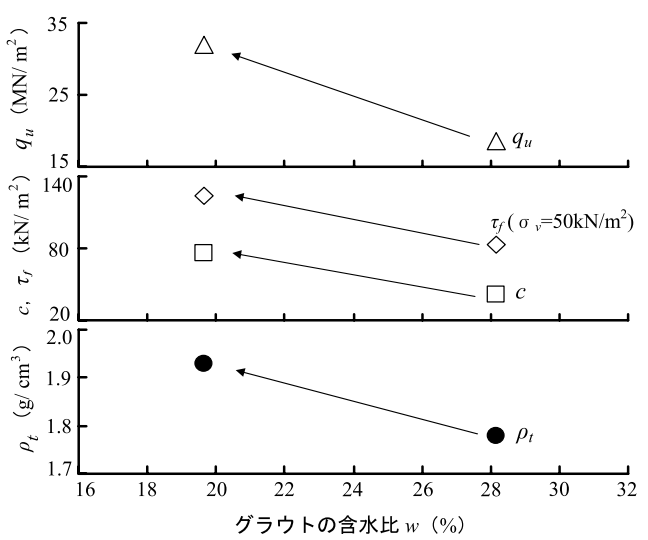

図一 8 グラウトの含水比と $q_{u}, c, \tau_{f}, \rho_{t}$ の関係（砂地盤）

Fig. 8 Relationship of $q_{u}, c$ and $\tau_{f}, \rho_{t}$ versus water content of grout (sand material)

発現する摩擦応力の違いなどから加圧注入の効果および て増加メカニズムについて考察した。その結果，以下の 知見が得られた。

(1) 今回の試験における地盤材全てにおいて，グラウト の加圧による浸透注入が認められなかったことから， 自然地盤の均質部に扔ける加圧注入ではグラウトの 浸透過程は生じ得ず，亀裂など地盤間隙の充填過程 が大半を占めるものと考えられる。

(2) 加圧注入によるグラウトの浸透過程は認められな かったものの，砂地盤と砂磁地盤の低い垂直応力時 $\left(\sigma_{v}=50 \mathrm{kN} / \mathrm{m}^{2}\right)$ において，加圧供試体の方が約 1.5 倍高い $\tau_{f}$ の差が涊められたことなどから，加圧注入 によりグラウトと地盤材接触面における付着力が増 加したことが示された。

（3）また，加圧注入により $\tau_{f} に$ 有意な差異が認められた 砂地盤と砂礫地盤については，加圧に伴うグラウト の脱水現象が顕著にみられ，砂地盤については脱水 による密害化の影響で，グラウトの強度が約 1.7 倍 増加したことが確認された。

(4) 加圧注入によりグラウトの脱水が効果的であれば, 密実なアンカー体が造成され，水密性や耐ブリージ ング性の向上が図れ，養生後のアンカー体周面の付 着力低下を抑制する効果があるものと判断される。

(5) 上記(1)〜(4)より，均質地盤における加圧注入による $\tau$ 増加のメカニズムは，グラウトの脱水現象に伴う 密実化および強度増加に起因する付着力の増加が主 要因であるものと考えられる。
今後は，地盤材の密度や加圧条件の異なる供試体につ いても試験を行い，加圧注入の有効性の変化を調べ，よ り詳細なて増加のメカニズムを明らかにしたい。

\section{謝辞}

本稿をまとめるにあたって, 山口大学大学院理工学研 究科の金折祐司教授ならびに山本哲朗教授には有益な助 言をいただきました。心から感謝いたします。

\section{引用文献}

1 ）社日本アンカー協会（2003）：グラウンドアンカー施工のため の手引書，22p，150p.

2 ) 社地盤工学会（2000）：グラウンドアンカー設計・施工基準, 同解説 (JGS4101-2000), 116p.

3 ) 社地盤工学会 (1997)：グラウンドアンカー工法の調査・設計 から施工まで, 9p.

4 ）最新地盤注入工法技術総覧編集委員会（1997）：最新地盤注入 工法技術総覧，産業技術サービスセンター, pp. 40-43, pp. $104-107$.

5 ) 社土質工学会 (1976)：アース・アンカー工法一付・土質工学 会アースアンカー設計・施工基準 - , 210p.

6 ）建設産業調査会（1987）：土木・建築技術者のための最新建築 基礎・地盤設計施工便覧，1003p.

7 ）グラウンドアンカー技術協会編（1996）：グラウンドアンカー 工法設計施工指針，森北出版，33p.

8 ）古賀誠・島田英樹・松井紀久男（2001）：均質地盤に対するグ ラウト材の一次元注入解析ーグラウチングにおけるグラウト 材の浸透挙動に関する研究 (第 1 報) - , 資源と素材, Vol.117, pp. $209-214$.

9 ）古賀誠・島田英樹・松井紀久男（2002）：グラウト材の模擬地 盤への注入実験とろ過理論を導入した注入解析の適用性一グ ラウチングにおけるグラウト材の浸透挙動に関する研究（第 2 報) - ，資源と素材，Vol.118，pp. 29-35.

10）伊藤次郎 (1976)：数学モデル, 丸善出版, pp. 15-17.

11）筒井通剛 - 山崎淳一 - 富山哲次 - 原郁正 ・稲村利男 (1992）: 永久地盤アンカー工法の研究 (その16.グラウト加圧力・加圧 時間とアンカー耐力の関係), 日本建築学会大会 (北陸) 学術 講演梗概集, pp. $1343-1344$.

12) Potyondy, J. G. (1961) : Skin Friction between Various Soils and Construction Materials, Geotechnique, Vol. 11, No. 4, pp. $339-353$.

13）新城俊也 - 小宮康明 - 永吉功治 - 国吉真文（2004）：砂と鋼材 の摩擦特性に及ぼす粒径と粗度の影響，琉球大学農学部学術 報告, 第51号, pp. 101-106.

14）林鍾鉄・龍岡文夫・宮崎啓一（1990）：砂地盤内の剛な鉛直ア ンカーの引抜き抵抗メカニズム，土と基礎，Vol. 38，No. 5, pp. $33-38$.

15）古賀誠・笹岡孝司 - 島田英樹 - 久保田士郎・松井紀久男 (2000)：破砕性岩盤へのグラウト注入に関する基礎的研究, 第21回西日本岩盤工学シンポジウム論文集, pp. 161-166.

16）有山峰夫・平野栄・根本恒（1990）：圧縮型本設地盤アンカー 工法に関する研究（その1）-アンカーの構造概要および掘り 出し結果 - , 第25回土質工学会研究発表講演集, pp. $1541-$ 1542.

17）小林勝巳・西村憲義・森本敏幸（1990）：圧縮型本設地盤アン カー工法に関する研究（その 2 ) -引抜き試験一，第25回土質 工学会研究発表講演集, pp. $1543-1546$.

18）栗原和夫・斉藤顕次・小林康之・田村昌仁（1992）：グラウト 圧によるアンカー体周面地盤の加圧状況，土木学会論文集， No. 453, pp. $145-154$.

19）大屋準三（1990）：PTC本設地盤アンカー工法，土と基礎， Vol. 38, No. 5, pp.9-14 (口絵写真-1). （原稿受付2008年 1 月 7 日，原稿受理2008年 6 月 5 日） 